\title{
Analisis Media Komunikasi Pemasaran dalam Penguatan Industri Kecil
}

\author{
Christina Rochayanti dan Reny Triwardani \\ Program Studi Ilmu Komunikasi UPN “Veteran” Yogyakarta \\ Jl.Babarsari No 2 Yogyakarta \\ Email: christina.rochayanti@upnyk.ac.id
}

\begin{abstract}
This study aims to analyze marketing communication media used by Women farmer group or KWT. KWT "Pawon Gendis " is a group of women farmers who produce processed products from the leaf of Pegagan into snack foods and local snacks. This research is aimed at developing web 2.0 marketing communications by using participatory action research method, which will place the domestic industry practitioners as an active participant in finding the model of marketing communication which is applied for their business. The results showed that Pawon Gendis Farmer Group (KWT) marketed more processed products using personal selling, by being purchased directly at production sites, sold at stands or through local food exhibitions. Social media used is WhatsApp and Facebook, both media platform is still limited as a means of communication media among members, customers, and media information activities of KWT members. Social media has not been utilized as a marketing medium, this is due to the limitations of internet network facilities and mastery of web 2.0 based communication technology.
\end{abstract}

Keywords: marketing communication, women farmers group, social media, home industry

\begin{abstract}
Abstrak
Penelitian ini bertujuan untuk menganalisis media komunikasi pemasaran yang digunakan oleh Kelompok Wanita Tani (KWT). KWT Pawon Gendis merupakan kelompok wanita tani yang memproduksi produk olahan dari daun pegagan menjadi produk makanan ringan dan jajanan lokal. Penelitian ini diarahkan pada pengembangan komunikasi pemasaran berbasis web 2.0 dengan menggunakan metode participatory action research, yang nantinya menempatkan pelaku usaha industri rumah tangga sebagai partisipan yang aktif dalam menemukan model komunikasi pemasaran yang tetap bagi usahanya. Hasil penelitian menunjukkan bahwa Kelompok Wanita Tani (KWT) Pawon Gendis, memasarkan produk olahan lebih banyak menggunakan personal selling, dengan cara dibeli langsung di tempat produksi, dijual di kios atau melalui berbagai pameran pangan lokal. Media sosial yang digunakan adalah WhatsApp dan Facebook, kedua media platform ini masih sebatas sebagai alat media komunikasi antaranggota, para pelanggan dan media informasi kegiatan anggota KWT. Media sosial belum dimanfaatkan sebagai media pemasaran, hal ini disebabkan karena keterbatasan sarana jaringan internet dan penguasaan teknologi komunikasi berbasis web 2.0.
\end{abstract}

Kata kunci: komunikasi pemasaran daun pegagan, kelompok wanita tani, media sosial, industri kecil 


\section{Pendahuluan}

Secara kualitatif peran usaha kecil dalam perekonomian nasional pun tidak diragukan. Pertama, usaha kecil dapat memperkokoh perekonomian nasional melalui berbagai keterkaitan usaha, seperti fungsi pemasok, fungsi produksi, fungsi penyalur dan pemasar bagi hasil produk-produk industri besar. Usaha kecil berfungsi sebagai transformator antar sektor yang mempunyai kaitan ke depan maupun ke belakang (forward and backwardlinkages). Bahkan, dalam perekonomian modern seperti sekarang ini tidak ada satupun mata rantai ekonomi yang semata-mata terdiri dari perusahaan besar dan semata-mata dari perusahaan kecil (Drucker, 2000) Kedua, usaha kecil dapat meningkatkan efisiensi ekonomi khususnya dalam menyerap sumber daya yang ada. Usaha kecil sangat fleksibel karena dapat menyerap tenaga kerja lokal, sumber daya lokal dan meningkatkan sumber daya manusia untuk menjadi wiraswasta yang tangguh. Karena sifatnya yang relatif fleksibel, usaha kecil mudah beradaptasi dengan lingkungan yang terbatas infrastrukturnya dibanding dengan usaha besar yang pada umumnya membutuhkan sumber daya dan dana yang besar. Pada usaha kecil, biaya umum dan resiko relatif kecil karena pemilihan lokasi mudah dilakukan. Ketiga, usaha kecil dipandang sebagai sarana pendistribusian pendapatan nasional. Usaha kecil tersebar ke pelosok tanah air, mulai dari perkotaan sampai dengan pedesaaan. Dalam transformasi struktur ekonomi nasional yang cenderung berubah dari ekonomi agraris ke ekonomi industri, sektor ini berfungsi sebagai transformator dan mobilisator tenaga kerja lokal.

Industri kecil dalam pengembangannya seringkali sulit beradaptasi dengan struktur pasar karena pada umumnya kurang memiliki informasi pasar sebagai akibat keterbatasan kemampuan yang dimiliki. Ini sering menjadi salah satu faktor bagi industri kecil untuk memperluas akses pasar. Akibatnya, ruang gerak secara ekonomis akan tetap lemah dan terbatas. Pada titik inilah peran infomasi pemasaran menjadi sangat penting dalam rangka mengubah keadaan yang product oriented menjadi market oriented.

Informasipemasaranmerupakantitiktolak untuk menyusun strategi. Informasi pemasaran didefinisikan diantara para ahli, banyak yang sejalan dengan konsep Kotler (2006;126), yang menekankan bahwa sistem informasi pemasaran ialah "suatu proses pengumpulan, pengolahan dan penyajian data menjadi informasi yang dilakukan secara sistematik untuk dijadikan masukan dalam pengambilan keputusan dalam menganalisis, perencanaan, implementasi dan pengendalian pemasaran." Untuk memperoleh informasi pemasaran, produsen harus menganalisis lingkungan pemasaran makro (ekonomi, teknologi, sosial budaya, peraturan/ kebijakan pemerintah, politik dan demografi) dan lingkungan pemasaran mikro (pemasok, pesaing, pasar/pelanggan, perantara dan publik). Informasi tentang lingkungan pemasaran (makro dan mikro) mempunyai ciri cepat berubah sejalan dengan perkembangan dunia bisnis, karena itu produsen yang menginginkan strategi pemasaran yang terarah harus selalu mempertimbangkan faktor-faktor lingkungan pemasaran tersebut.

Ketidakmampuandalammengidentifikasi kebutuhan dan keinginan pembeli terhadap produk yang ditawarkan Usaha Kecil Menengah atau UKM dapat dicarikan solusinya melalui komunikasi pemasaran berbasis web. Teknologi komunikasi pada level industri dapat dimanfaatkan bagi pelaku usaha sebagai media promosi dan periklanan. Perkembangan teknologi komunikasi telah menjadi fenomena yang tumbuh dengan sangat pesat. Media baru seperti internet, yang mampu menembus batas wilayah, budaya, dan kelas sosial. Internet kini telah menjadi bagian dunia global yang dapat diakses secara universal dengan biaya yang sangat ringan (Brannan, 2005:91).

Web 2.0. ialah suatu aktifitas interaktif yang terjadi di internet, yang bisa membuat produk dan gerakan yang baru. Filosofi dari Web 2.0 adalah pengunjung bisa berpartisipasi aktif di website. Pemasaran melalui berbagai website 
yang berbasis Web 2.0 pada umumnya bertujuan sama, yakni membangun dan mencerdaskan komunitas pelanggan dan dapat menimbulkan minat melakukan pembelian terhadap produk tersebut. Titik berat strategi pemasaran usaha kecil berbasis web 2.0 adalah mewujudkan produk usaha kecil yang partisipatif dengan menjalin komunikasi dua arah antara produsen dan pelanggan berbasis Web 2.0. Dengan demikian yang terjadi tidak hanya otomatisasi pemasaran produk saja, tetapi lebih dari itu terjadi efisiensi serta peningkatan citra produk di hadapan pelanggan yang akan dijadikan target pasar produknya sehingga pelanggan melakukan keputusan pembelian terhadap produk yang ditawarkan oleh usaha kecil dan pada akhirnya dapat meningkatkan daya saing industri kecil.

Kelompok wanita tani Pawon Gendis berusaha memberdayakan wanita untuk berusaha memanfaatkan tanaman sekitar yang diolah menjadi industri rumah tangga dengan nilai jual yang tinggi. Kelompok wanita tani yang kemudian disebut KWT bergerak di bidang industri rumah tangga (home industry) pengelolaan daun Pegagan menjadi makanan ringan dan jajanan lokal. Kelompok ini semula adalah kelompok tani budidaya Pegagan yang bergerak pada membudidayakan Pegagan sebagai bahan baku produk olahan seperti makanan ringan dan kemasan minuman berupa serbuk yang berkasiat bagi kesehatan. Kelompok wanita tani budidaya Pegagan ini berada di desa Salakmalang Banjarharjo Kalibawang Kulon Progo Daerah Istimewa Yogyakarta (DIY). Sesuai pandangan pemerintahan desa Banjarharjo (RPJMDes. 2013-2014) bahwa:

Perempuan sebagai mitra sejajar dengan pria dalam proses pembangunan harus lebih diberdayakan dengan tetap memperhatikan kodrat dan martabatnya. Untuk meningkatkan peran wanita dalam pembangunan, maka perlu pemberdayaan perempuan melalui peningkatan pengetahuan ketrampilan dan keahlian serta dilibatkan dalam proses pembangunan mulai dari perencanaan, pelaksanaan dan pengendalian. Penduduk wanita di Desa Banjarharjo 4.104 orang atau $53,87 \%$, ini berarti penduduk wanita jauh lebih banyak dibandingkan dengan kaum laki-lakinya.

Penelitian ini bertujuan untuk melakukan analisis pada media komunikasi pemasaran KWT Pawon Gendis dalam upaya penguatan industri rumah tangga produk Daun Pegagan di Kulon Progo. Dengan melakukan analisis model komunikasi pemasaran KWT Pawon Gendis, diharapkan pengembangan model pemasaran berbasis teknologi komunikasi dapat meningkatkan kesejahteraan usaha kecil dan menengah ini.

Penelitian tentang komunikasi pemasaran sudah banyak dilakukan. Diantarannya adalah Penelitian Afifi dan Susilo (2014) tentang komunikasi pemasaran sekolah, Utomo (2013) yang berkaitan dengan komunikasi pemasaran sosial terhadap kesadaran hidup sehat peternak di Kecamatan Selo Boyolali dan Nurticayanti (2015) yang mengangkat tema komunikasi pemasaran paguyuban batik tulis di Bantul. Berdasarkan penelitian sebelumnya menyebutkan bahwa komunikasi pemasaran dalam kegiatan sosial maupun ekonomi sangat penting dan diperlukan inovasi cara pengembangan komunikasi pemasaran yang dilakukan. Merujuk pada penelitian Afifi dan Susilo (2014) berhasil mengidentifikasikan penggunaan internet sebagai media promosi sekolah. Pengembangan komunikasi pemasaran yang berhasil dilakukan adalah pembuatan profil audio visual sekolah, workshop manajemen sekolah, partisipasi mitra khususnya dalam memberikan beasiswa, adanya community relations dan pelatihan dalam pembuatan media promosi seperti meningkatkan minat orang tua untuk memilih sekolah tersebut. Komunikasi pemasaran juga dapat meningkatkan kesadaran hidup sehat para peternak sapi. Pada penelitian Utomo (2013) disebutkan bahwa pemanfaatan komunikasi pemasaran dapat mengubah kebiasaan. Jika sebelumnya kebiasaan warga desa hidup satu 
rumah dengan binatang piaraannya khususnya sapi, yang dilakukan karena alasan masalah keamanan. Hasil penelitian menunjukkan ada perubahan kesadaran peternak sapi untuk bisa hidup sehat. Hasil serupa juga terjadi pada penelitian Nurficayanti (2015) bahwa komunikasi pemasaran pada industri rumah tangga dilakukan untuk menguatkan keanggotaan perajin batik dan juga menambah pengetahuan tentang manajemen pemasaran yang baik. Batik yang ditetapkan oleh UNESCO sebagai warisan dunia, perajin batik mulai mengembangkan usahanya dengan melibatkan penduduk lokal. Komunikasi pemasaran dilakukan dengan mengadakan kerjasama dengan pemerintah kabupaten dalam pembuatan seragam batik untuk pegawai negeri kabupaten, dan sekolah. Komunikasi pemasaran dalam paguyuban dapat meningkatkan ekonomi keluarga perajin sehinggga hidupnya semakin sejahtera.

Strategi bisnis dan keunggulan bersaing sangat penting untuk dijadikan pedoman dalam pengembangan strategi pemasaran. Para pengambil keputusan pemasaran dilibatkan dalam proses perencanaan bisnis pada tiga hal penting yaitu; (1) peran serta dalam analisis dan perencanaan strategik perusahaan, (2) melayani bersama manajer fungsional lain sebagai anggota tim perencaanan strategik unit bisnis dan (3) mengembangkan dan melaksanakan rencana-rencana pemasaran strategik untuk pasar yang dilayani perusahaan (Cravens, 2006), selanjutnya dalam perencanaan strategik kepala eksekutif pemasaran bertanggungjawab dalam (1) perumusan strategi perusahaan, (2) mengembangkan strategi pemasaran unit bisnis dalam mendukung prioritas perusahaan (Cravens, 2006).

Lebih lanjut, Kotler (2007) membagi strategi pemasaran menjadi tiga bagian penting, yaitu: (1) strategi pasar sasaran dan strategi penempatan produk, (2) bauran pemasaran dan anggaran pemasaran, serta (3) strategi pemasaran yang menyeluruh dikaitkan dengan tujuan serta sasaran penjualan, pangsa pasar dan keuntungan. Dalam hal ini, tujuan pemasaran merupakan arah bagi perusahaan untuk merumuskan alternatif strategi pemasaran.

Istilah industri sering diidentikkan dengan semua kegiatan ekonomi manusia yang mengolah barang mentah atau bahan baku menjadi barang setengah jadi atau barang jadi. Dari definisi tersebut, istilah industri sering disebut sebagai kegiatan manufaktur (manufacturing). Padahal, pengertian industri sangatlah luas, yaitu menyangkut semua kegiatan manusia dalam bidang ekonomi yang sifatnya produktif dan komersial. Disebabkan kegiatan ekonomi yang luas maka jumlah dan macam industri berbeda-beda untuk tiap negara atau daerah.

Pada umumnya, makin maju tingkat perkembangan perindustrian di suatu negara atau daerah, makin banyak jumlah dan macam industri, dan makin kompleks pula sifat kegiatan dan usaha tersebut. Cara penggolongan atau pengklasifikasian industri pun berbeda-beda. Tetapi pada dasarnya, pengklasifikasian industri didasarkan pada kriteria yaitu berdasarkan bahan baku, tenaga kerja, pangsa pasar, modal, atau jenis teknologi yang digunakan. Selain faktor-faktor tersebut, perkembangan dan pertumbuhan ekonomi suatu negara juga turut menentukan keanekaragaman industri negara tersebut, semakin besar dan kompleks kebutuhan masyarakat yang harus dipenuhi, maka semakin beranekaragam jenis industrinya. Adapun klasifikasi industri berdasarkan kriteria masingmasing (Siahaan, 1996), adalah sebagai berikut:

Berdasarkan jumlah tenaga kerja yang digunakan, industri dapat dibedakan menjadi: (a) Industri rumah tangga, yaitu industri yang menggunakan tenaga kerja kurang dari empat orang. Ciri industri ini memiliki modal yang sangat terbatas, tenaga kerja berasal dari anggota keluarga, dan pemilik atau pengelola industri biasanya kepala rumah tangga itu sendiri atau anggota keluarganya. Misalnya: industri anyaman, industri kerajinan, industri tempe/ tahu, dan industri makanan ringan;

(b) Industri kecil, yaitu industri yang tenaga kerjanya berjumlah sekitar 5 sampai 19 orang, 
Ciri industri kecil adalah memiliki modal yang relatif kecil, tenaga kerjanya berasal dari lingkungan sekitar atau masih ada hubungan saudara. Misalnya: industri genteng, industri batubata, dan industri pengolahan rotan;

(c) Industri sedang, yaitu industri yang menggunakan tenaga kerja sekitar 20 sampai 99 orang. Ciri industri sedang adalah memiliki modal yang cukup besar, tenaga kerja memiliki keterampilan tertentu, dan pimpinan perusahaan memiliki kemampuan manajerial tertentu. Misalnya: industri konveksi, industri bordir, dan industri keramik;

(d) Industri besar, yaitu industri dengan jumlah tenaga kerja lebih dari 100 orang. Ciri industri besar adalah memiliki modal besar yang dihimpun secara kolektif dalam bentuk pemilikan saham, tenaga kerja harus memiliki keterampilan khusus, dan pimpinan perusahaan dipilih melalui uji kemampuan dan kelayakan (fit and profer test). Misalnya: industri tekstil, industri mobil, industri besi baja, dan industri pesawat terbang.

\section{Metode Penelitian}

Penelitian diarahkan pada analisis media komunikasi pemasaran berbasis web 2.0 dalam penguatan industri rumah tangga dengan menggunakan metode participatory action research. Pelaku usaha industri rumah tangga sebagai partisipan yang aktif dalam menemukan menggunakan media komunikasi pemasaran yang tetap bagi usahanya.

Participatory action research atau disingkat PAR merupakan penelitian yang melibatkan secara aktif semua pihak-pihak yang relevan (stakeholders) dalam mengkaji tindakan yang sedang berlangsung (di mana pengalaman mereka sendiri sebagai persoalan) dalam rangka melakukan perubahan dan perbaikan ke arah yang lebih baik. Dalam PAR perlu melakukan refleksi kritis terhadap konteks sejarah, politik, budaya, ekonomi, geografis dan konteks lain-lain yang terkait (Afandi, 2014:91). Dengan kata lain, Participatory Action Research (PAR) yaitu metode riset yang dilaksanakan secara partisipatif di antara warga masyarakat dalam suatu komunitas aras bawah yang semangatnya untuk mendorong terjadinya aksi-aksi transformatif melakukan pembebasan masyarakat dari belenggu ideologi dan relasi kekuasan (perubahan kondisi hidup yang lebih baik). Pada konteks penelitian ini, pelibatan pelaku usaha industri rumah tangga dalam pemanfaatan media komunikasi pemasaran berbasis web 2.0 menjadi suatu upaya yang membangun pemberdayaan masyarakat dalam mengembangkan model komunikasi pemasaran yang terintegrasi dengan media baru internet. Adapun tahapan pelaksanaan penelitian ini adalah sebagai berikut:

\section{Gambar 1. Tahapan pelaksanaan penelitian}
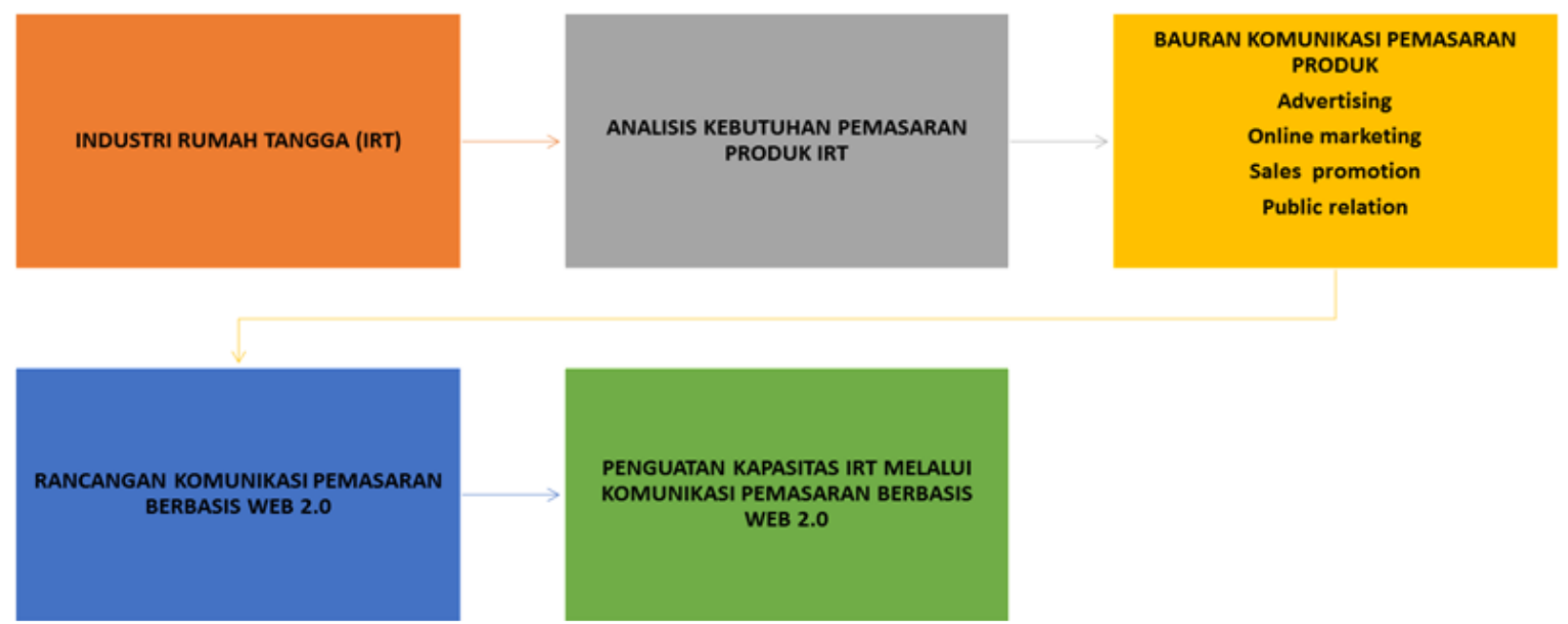


\section{Hasil Penelitian dan Pembahasan}

Desa Banjarharjo merupakan salah satu desa yang mengadakan pemberdayaan perempuan khususnya bagi ibu-ibu petani melalui program Kelompok Wanita Tani (KWT). KWT tersebut adalah wadah bagi para petani wanita untuk mengolah lahan pertanian sehingga menghasilkan panen yang bermanfaat bagi kehidupan keluarga dan masyarakat sekitarnya. Disinilah ibu-ibu dibimbing dan diberi pengetahuan tentang pengelolaan lahan pertanian. Pengetahuan yang diperoleh tersebut menjadikan ibu-ibu bertambah ketrampilannya dalam mengolah lahan pertanian mereka.KWT menjadikan perempuan lebih mandiri karena ibu-ibu yang tergabung dalam KWT mampu melihat peluang di lingkungan sekitarnya yang akan membawa pada pemulihan kondisi untuk menjadi lebih baik.

Pada hakekatnya permasalahan kesejahteraan sosial timbul dari dapat atau tidak terpenuhinya kebutuhan manusia. Permasalahan kesejahteraan sosial ada yang secara nyata berpangkal pada hambatan-hambatan dalam pemenuhan kebutuhan, ada yang timbul dan berkembang sebagai pengaruh dari perubahan sosial ekonomi, serta penggunaan ilmu serta teknologi dalam kehidupan manusia. Di samping itu juga permasalahan yang tidak dapat diprediksi sebelumnya seperti bencana alam. Kesejahteraan sosial adalah kondisi terpenuhinya segala kebutuhan seseorang melalui kegiatankegiatan yang bermanfaat bagi dirinya sehingga menimbulkan perasaan senang dan nyaman dalam menjalankan kehidupannya.

Kelompok Wanita Tani atau disingkat KWT adalah wadah bagi para petani wanita untuk mengolah lahan pertanian sehingga menghasilkan panen yang bermanfaat bagi kehidupan keluarga dan masyarakat sekitarnya. KWT merupakan kelompok swadaya yang tumbuh dari, oleh, dan untuk masyarakat serta bertujuan untuk meningkatkan cadangan pangan dan memajukan peran kelembagaan. Dengan demikian KWT merupakan kelompok yang tumbuh atas inisiatif dan kemauan serta kesadaran masyarakat sendiri guna ikut berpartisipasi aktif meningkatkan mengembangkan dan memberdayakan SDA dan SDM yang dimiliki dalam rangka meningkatkan cadangan pangan. Disinilah ibu-ibu dibimbing dan diberi pengetahuan tentang pengelolaan lahan pertanian.

Pada awalnya pemberdayaan perempuan melalui KWT di Dusun Salakmalang didasarkan pada kebutuhan masyarakat akan pangan. Kebutuhan pangan merupakan kebutuhan yang sangat penting disamping kebutuhan papan dan sandang. Kebutuhan pangan yang terpenuhi akan membawa hal positif pada ketahanan pangan dalam sebuah keluarga maupun di lingkungan masyarakat itu sendiri.

Berawal dari kelompok Dasawisma (10KK) di dusun Salakmalang, Banjarharjo tahun 2012 yang aktif mengolah produk makanan dengan menggunakan bahan baku lokal dan berlanjut menjadi kelompok wanita tani (KWT) Pawon Gendis. Berdiri pada tanggal 17 mei 2013 dengan nomor register 36/KWT/XI/ 2013 beranggotakan 29 orang. Pada perjalanannya, kelompok ini berkembang dan menarik minat ibu-ibu dilingkungan dusun Salakmalang untuk mengembnagkan diri bersama-sama kelompok dalam usaha pengolahan pangan berbahan baku lokal sehingga sejak 2014 KWT Pawon Gendis beranggotakan 42 orang.

\section{Media pemasaran produk olahan daun Pegagan KWT Pawon Gendis}

KWT Pawon Gendis bergerak dibidang olahan pangan berbahan baku lokal diantaranya umbi-umnbian, sayuran, bij-bijian, biofarmaka, peternakan, pertanian, nira kelapa. Semua bahan-bahan tersebut menghasilkan berbagai macam produk olahan kering dan olahan basah. Salah satu produk unggulan KWT Pawon Gendis adalah bahan olahan dari tanaman herbal Pegagan yang menghasilkan produk peyek Pegagan, coklat pegagan, minuman serbuk, teh celup pegagan, dan egg roll Pegagan.

Produk yang dihasilkan KWT Pawon Gendis dipasarkan secara langsung maupun tidak langsung. Strategi promosi pemasaran 
produk olahan basah dipasarkan secara langsung kepada konsumen dengan jangkauan pasar lokal dan sekitarnya. Anggota KWT Pawon Gendis memasarkan produknya masih terbatas pada pesanan langsung dari konsumen atau menggunakan sistem titip jual pada pengelola toko jajanan pasar.

Sedangkan produk olahan kering, promosi dan pemasaran nya relatif beragam dengan mekanisme langsung maupun tidak langsung. Beberapa bentuk komunikasi pemasaran yang dilakukan untuk produk unggulan olahan daun Pegagan diantaranya:

\section{Pameran /Bazar}

KWT Pawon Gendis aktif mengikuti pameran yang diadakan oleh berbagai instansi baik di wilayah DIY. Selain itu, beberapa perlombaan memasak atau menyajikan makanan pun diikuti guna menambah pengetahuan sekaligus media promosi produk olahan pangan yang dihasilkan

2. Personal Selling

KWT Pawon Gendis menyediakan produkproduk yang dihasilkan di secretariat yang juga menjadi tempat display produk olahan kering. Penjualan lansung dapat dilakukan dirumah ketua KWT Pawon Gendis, Ibu Dwi Martuti Rahayu, di dusun SalakMalang. Dalam perkembangannya, penjualan langsung juga bisa dilakukan di beberapa toko oleh-oleh yang menjadi mitra pemasaran KWT Pawon Gendis. Diantaranya sebagai berikut;
1. Toko oleh-oleh Sri Rejeki, Godean, DIY,

2. Toko oleh-oleh Sabar Menanti, Kalasan,DIY

3. Toko oleh-oleh Bumi Jawa, Bantul, DIY

4. Toko Agus, Kulon Progo,DIY

5. Toko TOMIRA, Kulon Progo,DIY

6. Toserba Bago, Kulon Progo,DIY

7. Galeri KOI (Komunitas Organik Indonesia),Kulon Progo

3. Liputan Media Massa

Berbagai liputan berita di media massa menjadi startegi promosi tidak langsung yang dilakukan baik di media cetak maupun media elektronik. Peliputan dari media elektronik pernah dilakukan oleh RCTI, SCTV, INDOSIAR, ANTV,TRANSTV, JOGJATV,TVRI JOGJA dengan tema pengolahan masakan berbahan baku serba pegagan. Peliputan dari media cetak seperti surat kabar KR, Sindo, Harian Jogja, Suara Merdeka tentang kegiatan KWT Pawon Gendis sekaligus produk unggulan serta prestasi yang diraih oleh kelompok ini.

4. Pemasaran Online

Promosi dan pemasaran produk olahan pangan KWT Pawon Gendis juga sudah menggunakan media sosial seperti Facebook dan Youtube. KWT Pawon Gendis belum memiliki akun secara mandiri tetapi melalui akun media sosial ketua KWT, produk olahan unggulan dipromosikan

\section{Gambar 2. contoh liputan berita surat kabar}

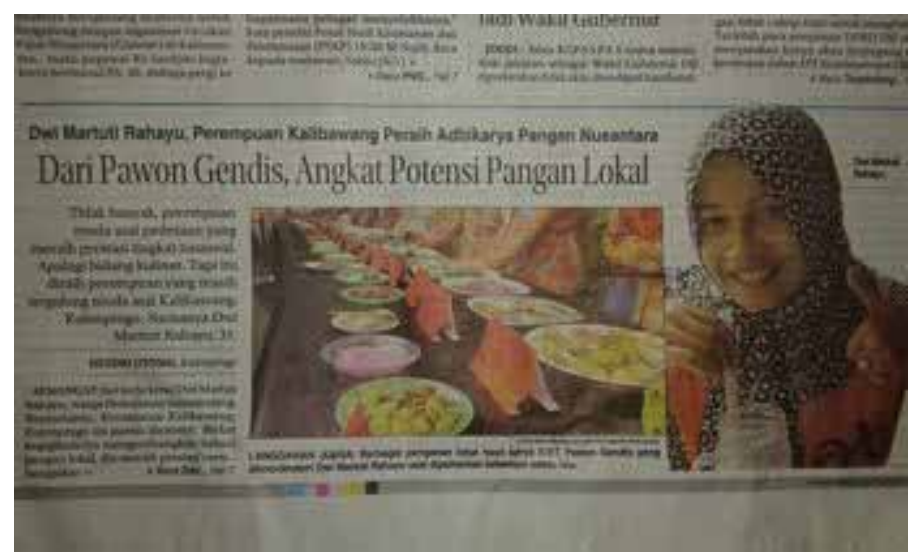




\section{Gambar 3 Tampilan akun facebook ketua KWT Pawon Gendis}

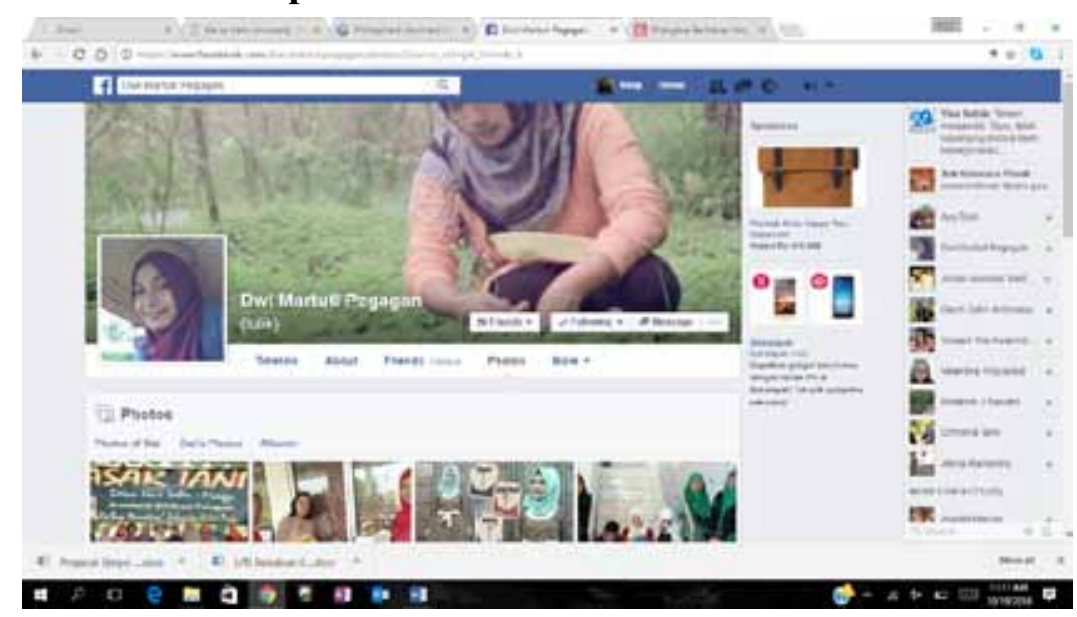

secara aktif dan mendapat respon yang cukup baik dari konsumen.

\section{Analisis Media Komunikasi Pemasaran KWT Pawon Gendis}

Komunikasi pemasaran yang dilakukan oleh produsen sebagai usaha menginfomasikan produk atau jasa yang dikelola supaya calon konsumen bersedia membeli atau memakai jasa yang ditawarkan (Kotler dan Keller, 2012: 498).

Media komunikasi pemasaran yang digunakan untuk memasarkan produk-produk yang dihasilkan KWT Pawon Gendis masih terbatas dengan sistem getok tular, artinya informasi tentang produk daun pegagan melalui informasi dari seseorang kemudian disebarkan lagi kepada orang yang sifatnya komunikasi antarmanusia. Hal ini terjadi karena keterbatasan sarana prasarana. Di samping pemasarannya juga melalui kerjasama dengan pihak lain, kemudian mereka menjual kembali sendiri.

Media pemasaran lainnya yang digunakan dengan cara personal selling. KWT Pawon Gendis langsung produk yang dihasilkan di kios yang disediakan oleh pemerintah kabupaten. KWT Pawon Gendis yang berada di wilayah Dusun Salakmalang Banjarharjo Kalibawang Kulon Progo, diberi fasilitas tempat berjualan oleh Pemerintah daerah di pasar Sentolo yang diarahkan sebagai sentral oleh-oleh khas Kulon Progo, ketika wisatawan berkunjung ke kabupaten Kulon Progo. Selain itu, kemitraan dengan sistem penjualan konsinyasi dilakukan dengan beberapa toko yang khusus menjual produk snack khas Kulon Progo.

KWT Pawon Gendis masih berorientasi memproduksi bagaimana cara menjual produk, mereka tidak berusaha untuk mengetahui kondisi pasar saat ini. Hal ini banyak dialami oleh industri rumah tangga di sekitar Kulon Progo khususnya di desa Banjarharjo, mereka hanya memproduksi saja kemudian diambil dengan cara borongan dan dijual lagi dipasar dengan harga yang lebih mahal. Demikian juga yang terjadi dengan KWT Pawon Gendis, jika produk berupa makanan basah, cara pemasaran yang dilakukan ialah berjualan di depan rumah atau di pasar di desa, sedangkan produk makanan kering dengan kemasan sudah bermitra dengan pemasok atau supplier yang mengambil kemudian dijual lagi kepada konsumen. Produk olahan pegagan seperti rempeyek dan coklat sudah dikenal dan banyak dibeli, namun belum dikenal secara luas sebatas wilayah Kulon Progo.

Keterbatasan informasi tentang pasar dan juga media komunkasi pemasaran terpadu untuk kelompok masih sangat kurang. Hal ini terjadi karena askes teknologi komunikasi dan juga akses menuju desa sebagai tempat produksi yang jauh dari pusat kota. Komunikasi pemasaran yang memanfaatkan teknologi komuniasi telah banyak dimanfaatkan oleh kalangan usaha sebagai media promosi. Di samping sebagai media promosi, komunikasi berbasis web 2.0 
juga dapat menjalin jaringan dengan pihak manapun. Namun demikian yang banyak dilakukan oleh KWT Pawon Gendis selama ini untuk berbagi informasi masih terbatas kegiatan internal dengan mengundang narasumber dari dinas pemerintahan maupun perguruan tinggi. Kelompok ini untuk mengenalkan dirinya juga sering mengikuti lomba makanan lokal di sekitar Yogyakarta yang banyak diselengarakan oleh dinas pemerintahan.

Penguasaan teknologi komunikasi yang berbasis internet telah digunakan oleh beberapa anggota namun terbatas sebagai media komunikasi seperti WhatsApp dan Facebook. Kedua media sosial ini masih terbatas sebagai media komunikasi dan sebagai media informasi kegiatan kelompok, belum dimanfaatkan sebagai media pemasaran produk. KWT Pawon Gendis sering mengikuti berbagai kegiatan lomba olahan pangan lokal baik tingkat lokal kabupaten maupun tingkat provinsi dan sering memperoleh juara. Produk daun pegagan yang memiliki khasiat untuk kesehatan adalah produk yang menjanjikan untuk bisa diterima masyarakat saat ini, karena kesadaran hidup sehat makin besar.

Penggunaan media komunikasi pemasaran dengan berbasis web dengan media sosial dapat dimanfaatkan untuk mengenalkan dan sekaligus memasarkan produk. Namun demikian penguasaan alat teknologi berbasis internet membutuhkan suatu ketrampilan dan manjemen pemasaran dan pelayanan yang professional. Hal ini membutuhkan pelatihan agar anggota KWT Pawon Gendis menjadi melek teknologi komunikasi berbasis internet dengan lebih baik. Faktor penghambat dalam pelaksanaan kegiatan komunikasi pemasaran produk KWT Pawon Gendis adalah SDM wanita tani belum dikembangkan secara maksimal. SDM wanita tani tersebut dipengaruhi oleh rendahnya pendidikan kaum perempuan yang menyulitkan penguasaan teknologi yang memungkinkan penggunaan komunikasi pemasaran online. Industri rumah tangga yang dikelola oleh kelompok wanita dapat memberikan penghasilan yang cukup baik untuk keluarga dan masyarakat sekitar. Penduduk desa tidak lagi berpikir menjadi pegawai negeri atau merantau ke luar kota, ke luar negeri, tetapi pekerjaan itu telah ada di sekitar tempat tinggal mereka.

\section{Simpulan}

Pemberdayaan perempuan melalui KWT Pawon Gendis di Desa Salakmalang, Banjarharjo antara lain pertemuan rutin bulanan yang di antaranya membahas tentang kegiatan-kegiatan KWT kedepan, kemajuan KWT, sosialisasi dari PPL yang berisi mengenai pengembangan program pengolahan produk makanan lokal. Kegiatan-kegiatan KWT telah berhasil membuat anggota KWT untuk menghasilkan produksi makanan bernilai ekonomis bersama dan berkembang menjadi suatu industri kecil.

Faktor pendukung kegiatan ekonomi dan pemasaran produk KWT Pawon Gendis yaitu partisipasi dan motivasi dari semua anggota KWT cukup tinggi, tersedianya fasilitas yang cukup mendukung di Desa Banjarharjo, adanya kerjasama yang baik dari berbagai instansi terkait khususnya di bidang pertanian, dan dukungan dari masyarakat sekitar cukup baik. Sekalipun demikian pelaksanaan kegiatan komunikasi pemasaran produk KWT Pawon Gendis masih terbatas pada model pemasaran sosial yang mengandalkan sistem penjualan langsung atau personal selling dan promosi melalui sistem word of mouth (WOM). Komunikasi pemasaran online dapat dilakukan dengan penguatan penggunaan media sosial diantara anggota KWT Pawon Gendis.

\section{Daftar Pustaka}

Afifi, Subhan dan Edy Susilo, 2014. Pengembangan Komunikasi Pemasaran Sekolah Jurnal Ilmu Komunikasi UPN "Veteran" Yogyakarta Volume 13, nomor 3 September-Desember 2014 Hal. 277287.

Afandi, Agus, dkk., Panduan Penyelenggaraan Kuliah Kerja Nyata (KKN) Transformatif dengan Metodologi Participatory Action Research (PAR), Surabaya: LPPM UIN 
Sunan Ampel, 2014.

Brannan, Tom. 2005. Integrated Marketing Communications- Edisi Kedua. Alih. Bahasa; Slamet. Penyunting Poppy Herawati. Jakarta; PPM

Cravens, David W, .2006. Pemasaran Strategis. Jakarta: Erlangga.

Kotler, Philip .2006. Manajemen pemasaran, jilid I, Edisi kesebelas, Jakarta, P.T. Indeks Gramedia.

Kotler, Philip. 2007. Manajemen Pemasaran, Jilid 2, Edisi 12, PT Indeks., Jakarta

Kotler Phillip, Kevin Lance Keller. 2012. Marketing Management 14 th edition. Jakarta: PT. Indeks Kelompok Gramedia.
Nurticahyanti, Fera, 2015. Komunikasi Pemasaran Paguyuban Batik Tulis . Jurnal Aspikom Volume 2, nomor 5, Juli 205, hal. 304-313.

Utomo, Sutrisno Satriyo, 2013. Komunikasi Pemasaran Sosial terhadap Kesadaran Hidup Sehat Peternak Di Kecamatan Selo Boyolali. Jurnal Ilmu Komunikasi UPN "Veteran" Yogyakarta. Volume 11, nomor 1 Januari-April 2013 hal. 59-67. 